\title{
The Relationship of the Macroeconomic Variables with the Growth of Garment Industry in Bangladesh
}

\author{
Sk. Alamgir Hossain ${ }^{1}$, K. M. Anwarul Islam²
}

${ }^{1}$ Lecturer, Department of Finance, Faculty of Business Studies, Jagannath University, Dhaka-1100, BANGLADESH

${ }^{2}$ Assistant Professor, Department of Business Administration, The Millennium University, Dhaka-1210, BANGLADESH

*Corresponding Contact:

Email: ai419bankingdu@gmail.com

Cell Phone: +8801768343171

\begin{abstract}
In this research paper, we have tried to find out the relationship between the growth rate of garment industry and the macroeconomic variables. And for this we have conducted three types of analysis. First one is quantitative analysis; a second one is qualitative analysis, and the last one is a beta concept. Quantitative analysis has covered graphical presentation and multiple regression analysis. The graphical presentation just provides an overall idea about the relationship of variables, but it is an abstract concept. In case of regression analysis, we have used one dependent variable that is the growth rate of garment industry and seven independent variables those are growth rate of real GDP, the unemployment rate, inflation rate, interest rate, level of stock market, exchange rate. And stata-10 software has been used to run the regression model. After running the programmed it is seen that there have some econometric problems. By using the logarithm, we have solved those problems. A multiple regression analysis has been made to know the extent to which these variables affect the garment export growth rate. From that analysis, it has been found that about $70 \%$ variations in the growth rate of garments export can be defined by these variables. Then an equation for predicting future garments export has been constructed. Qualitative analysis has encompassed economic and political issues. After this, for knowing the individual effect of the variables, a beta concept has been employed and from that analysis it has been found that no variable affect garments export to a large extent. At the end of the analysis it can be said that, individual effect of the macroeconomic variables on the growth rate of garments export is not much but when they are combined, they can influence the garments export growth rate. As they are also related with each other which means change in one macroeconomic variable may change all the other variables. Therefore, a combined effect always remains. So, we can say that macroeconomic variables influence the garment industry of our country but not to a great extent.
\end{abstract}

Keywords: Demutualization, Garment Industry, Macroeconomic Variables JEL Classification Code: E60, M10, L67, O14 


\section{INTRODUCTION}

There are few countries in the world which after being an underdeveloped and corrupted country is competing in the world with the countries which are dominating in the world garments exporting. Bangladesh is one of those countries. In the year 2010-2011 more than 78\% of export earnings have been generated from the ready-made garments(RMG) sector of this country (Osman, 2012). It is clearly showing that the RMG sector is playing the significant role in terms of value addition, foreign-exchange earnings, employment creation, poverty alleviation and empowerment of women of this country.

With a poor literacy rate of about $50 \%$ (CIA) this country bears a population of about 150 million. She has the 95th position among the countries of the world in terms of area whereas it has 8th position among the countries of the world in terms of population. This bulk population has led the people of this country to the ways of corruption. Those who are not capable of doing that are engaged either in agriculture or in the industrial sectors. As various natural calamities visit this country now and often, agriculture has become a loss projects for the people of this country. Therefore, they have come out of their agricultural firm and joined the industrial sectors. This has paved the way for the ready-made garments industries to flourish. As the number of workers is increasing, the wage is low, and this has made it possible for the garments of this country to be cost effective. This is helping the owners of the garments industry of this country to capture the foreign market. In this research paper, the influence of the macroeconomic variables on this garment industry will be checked. It is important to know this influence for taking effective and timely decisions about this industry.

\section{LITERATURE REVIEW}

In the McKinsey Report 2011 named “Bangladesh's ready-made garments landscape: The challenge of growth" McKinsey \& company has tried to find out the future potential of being a hot spot of Bangladesh in the near future in the global RMG market. They have given an opinion that Bangladesh is the next hot spot after China (McKinsey, 2011).

In a monthly report of Unnayan Onneshon, it has been found that the GDP has increased over the years only because of the growth of the garment industry but it is not shown there that how much the garment industry has been modified by the growth of GDP (Unnayan Onneshon, 2010). This field needs to be researched. There are also other components of GDP besides garments industry. Do the developments of those components hasten the development of garment industry? The answer in this question should be found out.

In a report of $\mathrm{CPD}$, the growth of garment industry has been marked by the unemployment rate of Bangladesh. In another research, Stanely Fischer has found that, broad macroeconomic stabilization is required for sustainable development in any sector of any country (Fischer, 2001). Therefore, it can be said indirectly that macroeconomic variables affecting every growth aspect of any country and the garment industry is also included in the list of these aspect.

The intertemporal capital asset pricing model (ICAPM) of Merton (1973) suggests that state variables that predict time variation in future investment opportunity sets should be included as factors in asset pricing models. Among the most important candidates for state variables in multi-factor asset pricing models are innovations in macroeconomic variables such as GDP or consumption growth, employment rate and short-term interest rates (Cenesizoglu, 2010).

This sort of analysis has been done on the Indonesian economy. In one of the study, the results suggest that, domestic textile production was affected by world cotton price and wage rate, while the domestic garment production was affected by wage rate in the garment sector. Indonesia's textile export to world market was influenced by domestic textile price, and Indonesia's export garment was influenced by exchange rate (Rup/US\$). Indonesian textile 
demand was affected by wage rate while domestic garment demand was affected by income per capita of Indonesia (Iwan Hermawan, 2011).

In Malawi, an underdeveloped African country, transport costs are one of the biggest barriers to investment in and trade (Haan, Koen, \& Mthembu, 2002). From this perspective they find a negative relationship of the growth of garment industry with the transport costs.

In Srilanka, the garment industry is seriously being hampered by the low wage rate of the garment workers (B. Gowthaman \& Prasanna, 2007). They found out that the unemployment rate somewhat is negatively related with the apparel industry growth. When the unemployment rate has decreased the wage rate has also decreased and this in turn hampering the garment industry.

In a sub-Saharan country, Zambia, a relationship between the trade liberalization and the growth of garment industry can be found (Koyi, 2006). In a research paper, the author tried to say that, for a long time, Zambia has casualties in having growth in the garment industry. Since 1991, this country was so swift in changing the macroeconomic policies. That change has made many supporting industry of garments shut down. As a result, the growth of the garment industry remained slow in those years. Therefore, here we find a direct relationship of the growth of the garment industry with trade liberalization.

In Jordan, a significant relationship has been found between the evolvement of the garment industry and the stock of the human capital and persistent the unemployment rate. According to the opinion of the authors, the apparel industry has emerged in those countries because of those two macroeconomic variables (Domat, Glass, \& Brown, 2012).

In a comprehensive analysis on this field, the relationship between the business cycle and some industries has been found out (Berman \& Pfleeger, 1997). Among the tested industries there was miscellaneous fabricated textile industry. The author has tested this relationship by comparing the GDP with the industry demand and the situation of the employment. The historical correlation coefficient of employment condition with the textile industry was .8191 and the historical correlation coefficient of household demand with this industry was .8101. The projected correlation coefficient is .7430 (Berman \& Pfleeger, 1997). From this analysis, it is easily determinable that there is a relationship between the garment industry and the GDP.

\section{OBJectives OF THE RESEARCH}

- To know the effect of the macroeconomic variables on the garment industry

- To explore the challenges that this industry faces regarding the macroeconomic environment

- To explore the main contributing sector of our economy from a closer angle

- To know the ways by which the amount of sensitivity between variables can be identified

- To learn how to use the formula of one concept into another calculation to get the desired the result

\section{Research Methodology}

In this research paper, secondary data was used which was collected from various secondary sources such as Bangladesh Garment Manufacturers (BGM) and Exporters Association (BGMEA), Bangladesh Knitwear Manufacturers \& Exporters Association (BKMEA), World Bank, Monetary Fund, World Trade Organization (WTO) \& Books and Journals, Internet. Among the variables, Microsoft Excel \& STATA 10 was used to derive these statistical applications: - Bar Diagram, Line Chart, Area Chart, and Regression Analysis \& Correlation Analysis. After this, the methods analyzing the collected primary data testifying the perfection of the collected data were described. 


\section{OVERVIEW OF THE GARMENT INDUSTRY OF BANGLADESH}

The history of Bangladeshi garments starts only 40 years ago, after the end of liberation war. After getting freedom from the Pakistani oppressors, while restructuring the country, this industry did not develop much. The flourishing of this industry started from the early eighties. In those years, tea and jute were the most export oriented sectors of this country. But as the days passed by, the garments sector started to take the place of our golden crop from the late eighties. This industry began to contribute noticeably in the GDP from those years. With the passage of time, now this industry is the largest industry in the total foreign earnings and one of the largest in the GDP of Bangladesh.

As always this industry has made the employment opportunity easy, especially for the women. As a result, more than 2.7 million female have found their working destination in this industry that is $90 \%$ of the total workers (Wikipedia, Bangladesh Textile Industry, 2012).

Though the first industry was established in 1976 (Alam, Blanch, \& Smith, 2011), the RMG Export Started in 1978 (Wikipedia, Bangladesh Textile Industry, 2012). Though this industry, has spectacularly, this growth of the industry was hindered by the lack of supply chain improvement for many years. For example, until 1994 this industry was mainly dependent on the imported fabrics (Wikipedia, Bangladesh Textile Industry, 2012).

Now the textile industry of this country is described specifically under various headings for having a clear understanding of the export potentials of this industry of this country:

\section{OVERVIEW OF THE TEXTILE INDUSTRY OF BANGLADESH}

The textile industry of Bangladesh is the primary sources of earning foreign currencies for the last two or three decades. It has been the main source of export and formal employment. About 40 percent of the manufacturing populations have been employed in this industry and about 10 million people directly or indirectly are related with this industry (Acevedo, et al., 2012). There are several factors that have worked in favor of the development of the apparel industry of this country, such as:

- $\quad$ The Multifibre Arrangement (MFA)

- Preferential market access to the European Union

- Particular government assistance policies, etc.

Though the apparel sector of Bangladesh started in the late-1970s, the development of this sector started in the 1980s. This happened because in that time several manufacturers from the Republic of Korea and other East Asian countries began to invest in this sector of this country. They tried to create a source out of Bangladesh influenced by the arousal of some golden opportunities, such as the MFA quota hopping and the access to this country's abundant supply of low-cost labor. Along with the foreign investors, local producers also started to invest in this sector. They followed the foreign investors and established garment industries. They are also motivated by several success factors:

- Markets warranted by the quotas

- Very low investment requirement

- Getting help in the initial technology and know-how from the foreign investors.

Though it has been feared that after the MFA phase out the apparel sector of Bangladesh will fall in an uncertain situation, this sector of this country has in contrast enhanced its export value and the overall market share after 2044. Another noticeable achievement of this sector is, during the global economic crisis, Bangladesh's apparel sector has been one of the few winners that have increased the market shares both in America and the EU-15 (Acevedo, et al., 2012).

The main reason behind this achievement is the competitive advantage that Bangladesh has over its labor cost. It has the lowest labor cost among the main exporters of the garment products in 
the global apparel market. Besides the low costs, it has other competitive advantages too (Acevedo, et al., 2012). Some of them are:

- Having a comparatively long experience in this sector

- Broad contribution by the locals by local ownership and entrepreneurship

- The capability of backward linkages to local apparel suppliers

- Capabilities in addition to cut-make-trim (CMT) production that have ensured the profitability relative to other sectors and countries even in the most uncertain and competitive post MFA period.

- Upgrading in the process, functional and supply chain, etc.

\section{Data Analysis}

With the data analysis, the main problems and opportunities that the garments manufacturers or exporters have will come out conspicuously to the careful eyes of the concerned authority and they will be able to find ways to neutralize its threats and weaknesses. By taking a good care of the internal and external environmental factors, the garments associates of Bangladesh will be able to formulate effective and successful strategies.

For having a primary idea about these variables in terms of garments export, the graphical presentation of the above data is given below:

\section{Graphical Presentation of the Variables}

One by one graphical presentation of the above variables in the relation with garments export is given below:

\section{Garments export and the interest rate}

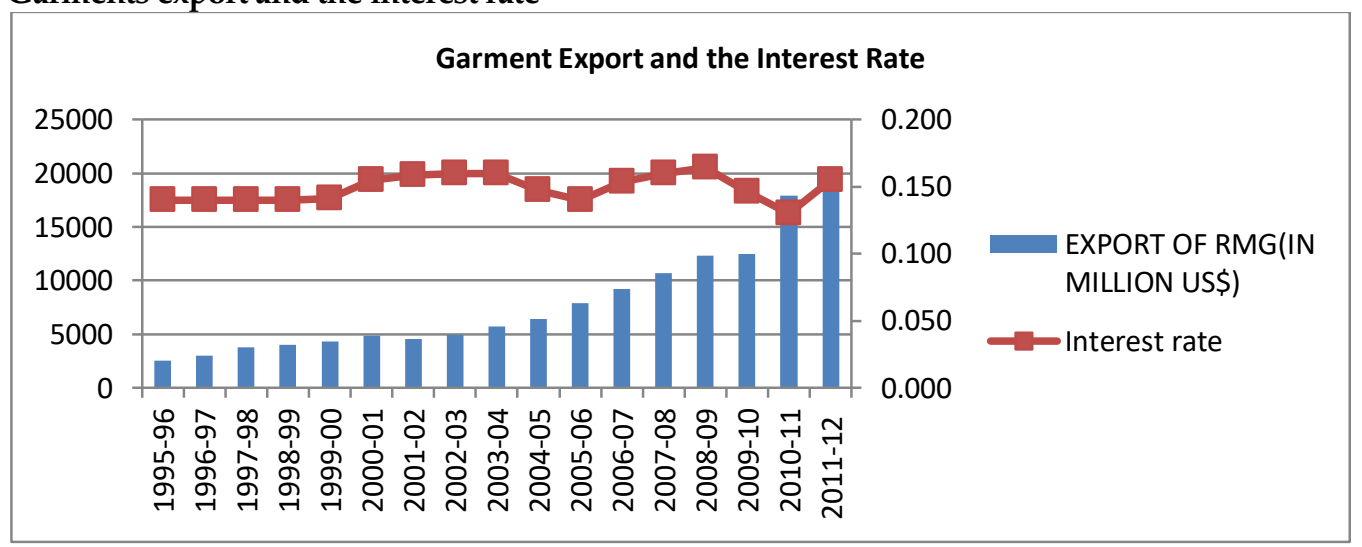

Figure 1: Graph of Garments Export and the Interest Rate

From the above picture, it can be said that the interest rate over the years is more or less constant. The lowest point occurred in 2010-11 and the reason is that it was the period when Bangladesh Bank initiated a contractionary monetary policy, and the banks were bound to reduce the interest rate. In recent times this situation has improved a little. Therefore, this rate is rising again. On the other hand, the export of garments is rising at a more or less constant rate. 


\section{Garments Export And The Inflation Rate}

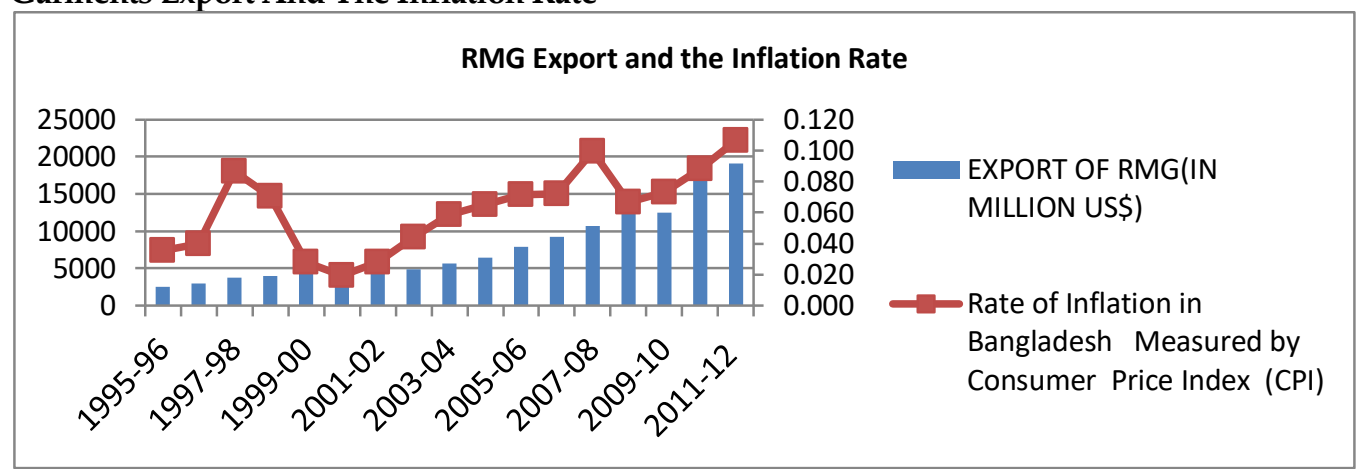

Figure 2: Graph of Garments Export and the Inflation Rate

From the above graph, we see the inflation is rising with the rise of garments export. In recent times, we see a high rise in the inflation rate, the reasons behind this rise is that the fuel price has been risen by the government at regular intervals and it can be said that several incidents such as, stock market crash and the fall of some Multilevel Marketing companies has contributed to the rising of the inflation. But this rising is helping garment industry to earn more foreign currency. This result follows the rule that when inflation rate rises the export will most benefit the exporters and this may be one of the reasons why our garments industry has developed the most.

\section{Garment Export and The Exchange Rate}

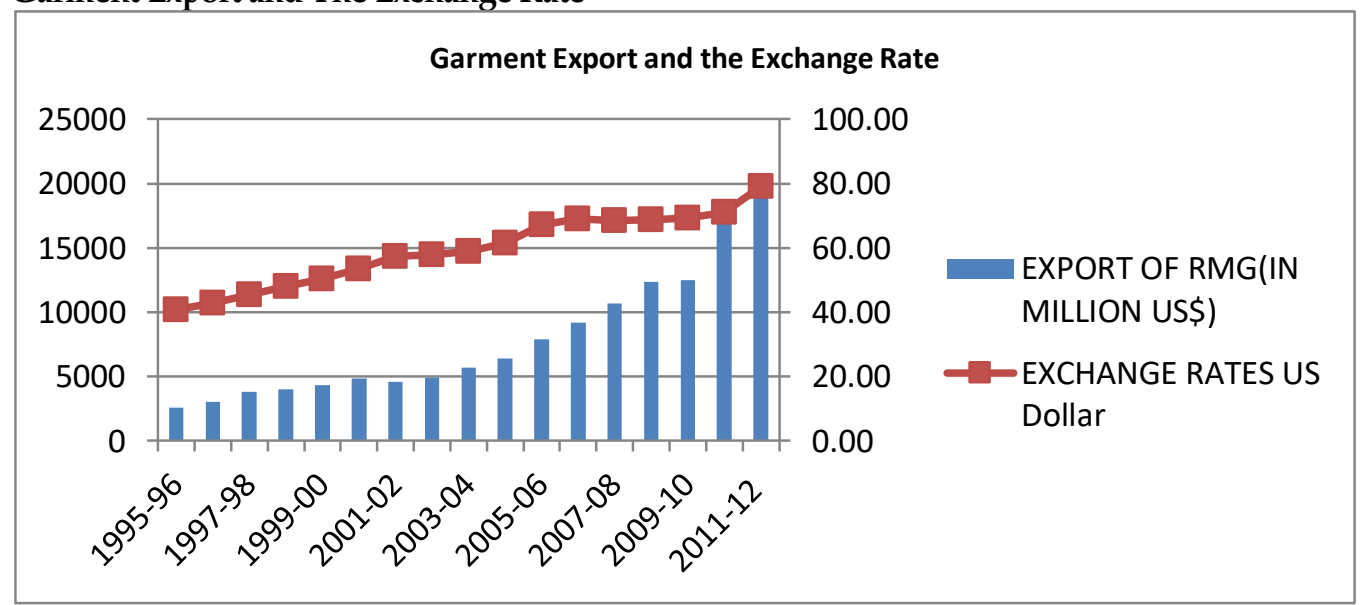

Figure 3: Graph of Garments Export and the Exchange Rate

This also proves the previously stated rule. With the exchange rate increasing the export, will most benefit the exporters. This has happened mainly due to the rising inflation in the recent years. As the inflation rate increases, the exchange rate also increases and this in turn is facilitating the garment export of our country. 


\section{Garments Export and the GDP}

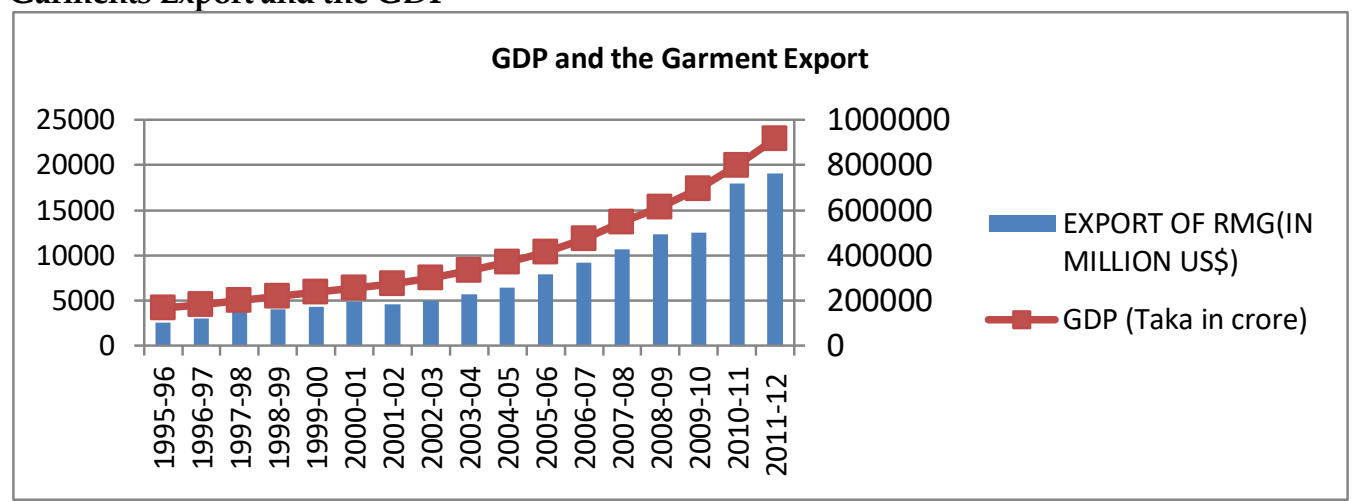

Figure 4: Graph of Garments Export and the GDP

This shows an almost perfect positive relation of RMG export with the growth of GDP. GDP of our country has been growing at an almost constant rate of around $6.5 \%$. Along with the GDP, the export of RMG has also been increasing. The GDP consists of the support industry of garment industry. If the support industries do not grow, as symbolized by the GDP, the Garment will not grow. This is similar to the result of an analysis by literature in the literature review chapter. From this simple graph, we can easily comment that there is a significant relationship between the RMG export and GDP growth rate.

\section{Garments export and Credit to the Public Sector}

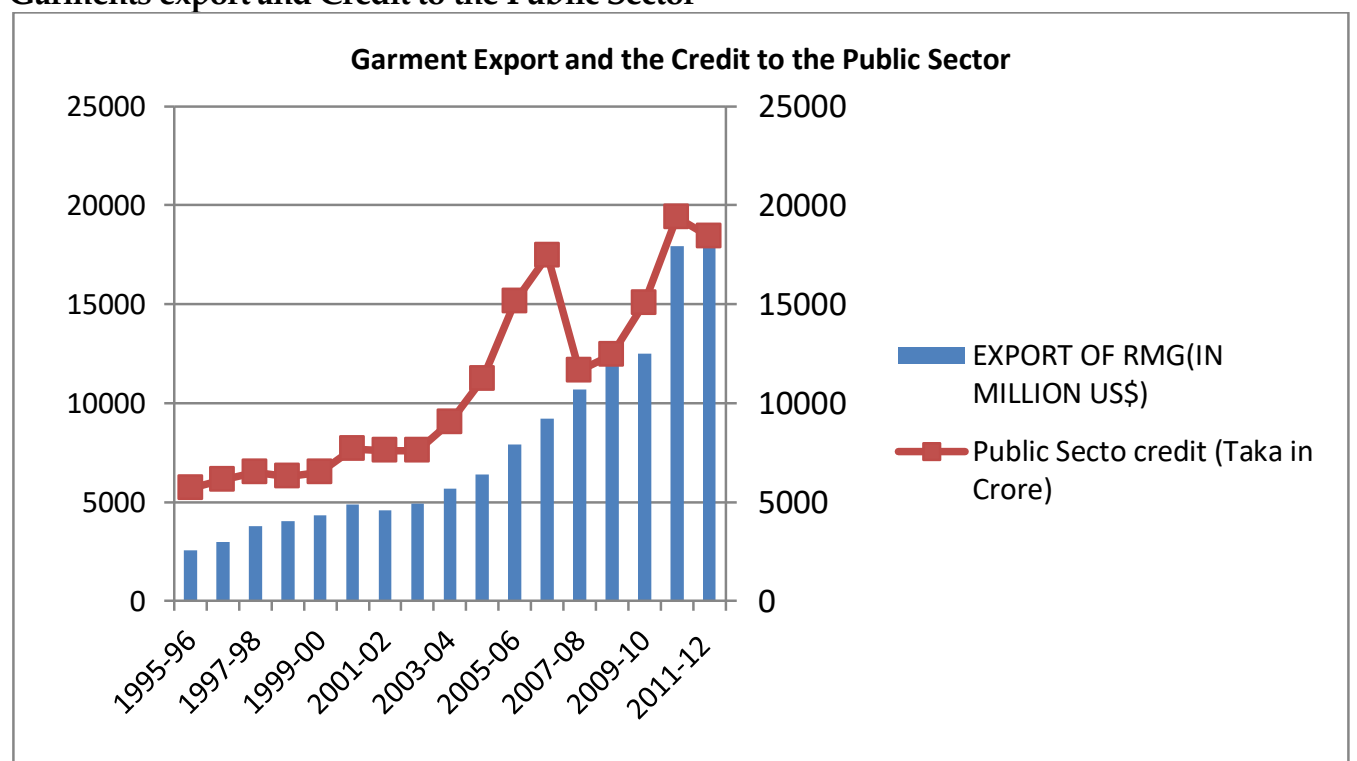

Figure 5: Graph of Garments Export and the Credit to the Public Sector

Here also we see a positive relationship of garments export with the provided credit to the public. In 2007-08, this amount was the lowest, and it is because in that period the government started to take a loan from the private banking sector. As the government started to take loan from the private sector, the credit to public started to decrease. Logically it can harm the investment rate of any country. But here the fluctuation of this rate graphically is not influencing 
the increasing growth rate of RMG export. Therefore, it can be said that credit provided to the public sector does not significantly influence the RMG export.

\section{Garment Export and Stock Market Capitalization}

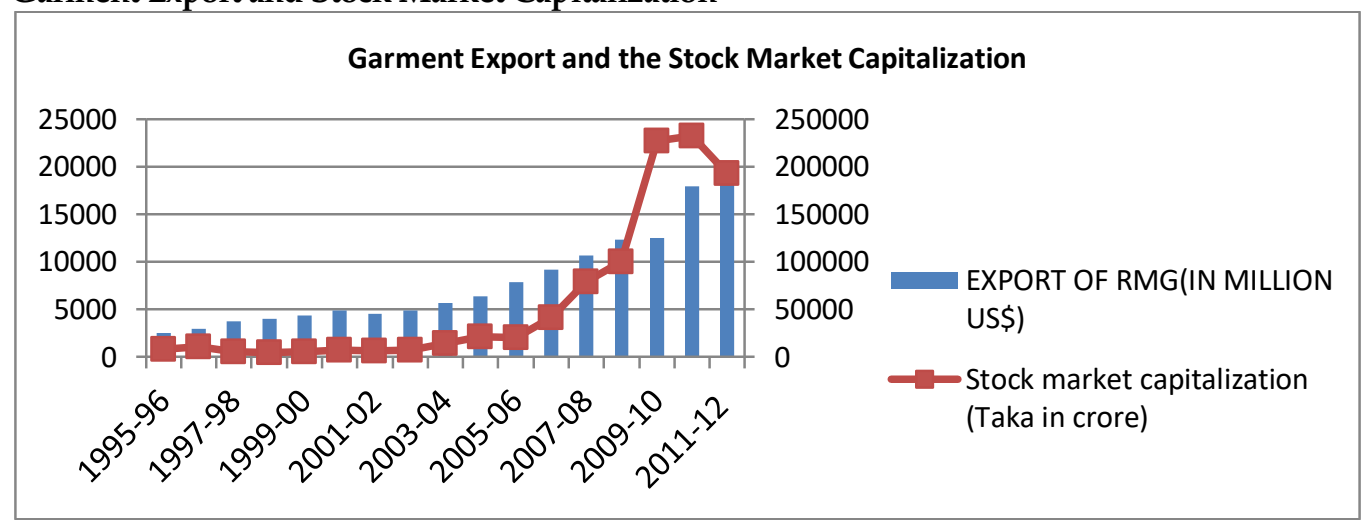

Figure 6: Graph of Garments Export and the Share Market Capitalization

This graph also exerts a positive relation of garments export with the share market capitalization. Here we see that, at the end of 2007-08 there is a sudden increase in the market capitalization. This has happened due to the stock bubble that has crashed the stock market at the end of 201011. From that time, the index, as well as the market capitalization is on decreasing path. This represents a great fluctuation in the stock market capitalization. However, this fluctuation has not influenced the growth rate of the garment sector significantly as we can see the increasing trend of RMG export over those fluctuating years. From this point of view, we can say stock market capitalization does not influence the garment industry of our country.

\section{Garments export and the unemployment rate}

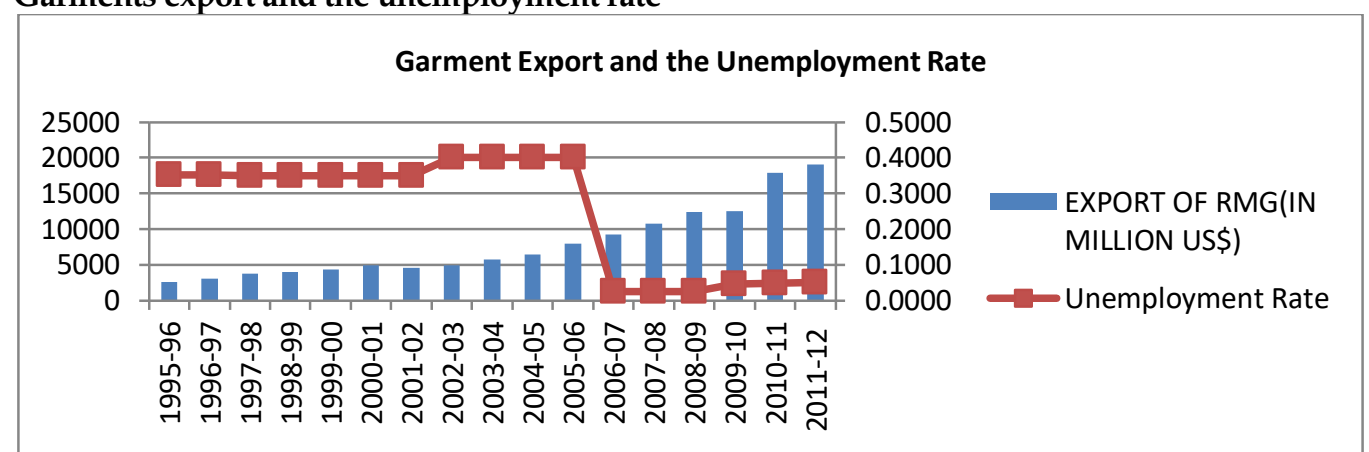

Figure 7: Graph of Garments Export and the Unemployment Rate

This graph creates confusion. The sudden drop of the unemployment rate marks the betterment of our country, but it has been found in the literature review that the unemployment rate was one of the reasons why the garments industry has flourished so much in our country. However, in later years this graph is showing a contradictory result in the sense that the garments export should lower when the unemployment rate decreases, whereas the export has risen even when the unemployment rate has decreased. So unlike the literature, the unemployment rate of our country does not significantly influence the garment industry. 
So far, this graphical presentation may give some ideas about the relationships. However, from the graph we cannot say the extent to which all variables, define the garments export. In the later part of the analysis, a quantitative analysis may give the answer to this query.

\section{Multiple Regression Analysis}

We have already seen the graphical presentation of the macroeconomic variables in relation of RMG export. That graphical presentation may give an overall idea about the relationship of the variables, but it is an abstract concept. We will now check out a more concrete measure of the relationship. This model is known as multiple regression models. This analysis is shown below:

\section{The results of the multiple regression analysis}

This model is run by the statistical package STATA 10. The output of the analysis by that software is given below:

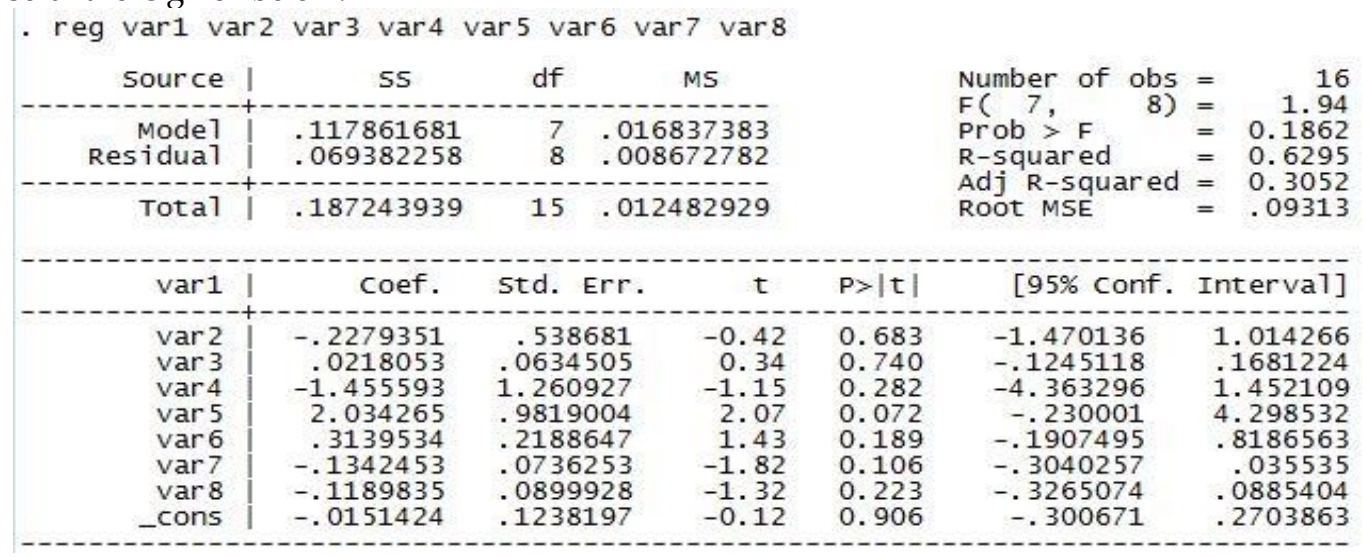

From the above output, we can point out the following findings:

- As the P-value associated with F-value is greater than .05, the independent variables do not reliably predicts the behaviour of the dependent variable.

- Here we can assume the value of alpha to be 1 and by considering this analysis as twotailed we can compare the t-value with alpha. From the comparison we can see only the variable 5 or the growth rate of GDP is statistically significant in terms of influencing the growth rate of RMG export.

- $62.95 \%$ of the export of garment products can be defined by these seven macroeconomic variables.

- The growth rate of interest rate, exchange rate, stock market capitalization and the unemployment rate have a negative influence on the growth rate of the export of garments.

- The growth rates of the inflation rate, GDP, and credit provided to the public sector have a positive relationship with the garments export.

- If all the variables have no impact on the garment export then garments export will reduce by $1.5 \%$.

\section{Econometric problems}

Three main econometric problems have been tested here. They are:

- Heteroskedasticity problem

- Autocorrelation problem

- Multicollinearity problem 
The tests regarding these problems are described below:

\section{Heteroskedasticity problem}

Two tests have been applied to detect and solve this problem. One is plotting method and the other one is Breusch-Pagan test. The outputs of these tests are shown in the appendices.

It is to be noted that, there was no problem of Heteroskedasticity in this multiple regression analysis.

\section{Autocorrelation problem}

To detect this problem, Durbin Watson test of auto correlation problem has been used. The output of the test has been shown in the appendices. Here also we found no problem of the autocorrelation in this analysis.

\section{Multicollinearity problem}

To see this problem, correlation matrix has no better alternative. At first, when I used the simple growth rate of variables in the analysis there was a small Multicollinearity problem. It can be shown in the following output of the analysis:

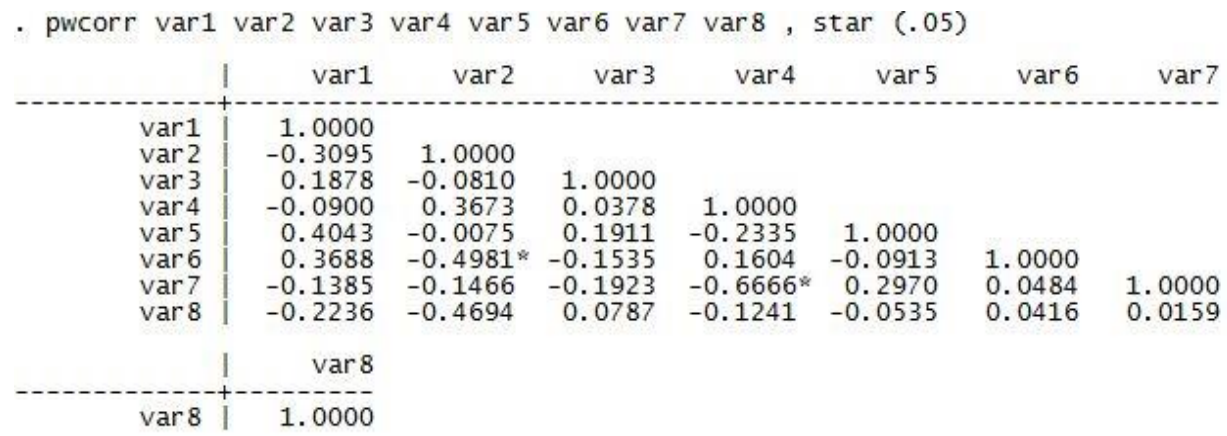

From the command line, it can be noted that, whenever any relationship between any two independent variables has a significance level below $5 \%$ the star sign will appear. In the above output we see star sign in two correlation coefficients. Therefore, we can say that, here there is a problem of Multicollinearity.

As a solution of this problem, we took the logarithm of the growth rate of variable "Credit provided to the public sector". Then again, we run the above command, and we found the following output:

- pwcorr var1 var 2 var 3 var 4 var 5 logvar6 var7 var 8

\begin{tabular}{|c|c|c|c|c|c|c|c|}
\hline & var1 & $\operatorname{var} 2$ & $\operatorname{var} 3$ & var 4 & $\operatorname{var} 5$ & logvar 6 & var 7 \\
\hline $\begin{array}{r}\operatorname{var} 1 \\
\operatorname{var} 2 \\
\operatorname{var} 3 \\
\operatorname{var} 4 \\
\operatorname{var} 5 \\
109 \operatorname{var} 6 \\
\operatorname{var} 7 \\
\operatorname{var} 8\end{array}$ & $\begin{array}{r}1.0000 \\
-0.3095 \\
0.1878 \\
-0.0900 \\
0.4043 \\
0.3556 \\
-0.1385 \\
-0.2236\end{array}$ & $\begin{array}{r}1.0000 \\
-0.0810 \\
0.3673 \\
-0.0075 \\
-0.2789 \\
-0.1466 \\
-0.4694\end{array}$ & $\begin{array}{r}1.0000 \\
0.0378 \\
0.1911 \\
-0.2026 \\
-0.1923 \\
0.0787\end{array}$ & $\begin{array}{r}1.0000 \\
-0.2335 \\
0.3295 \\
-0.6666 \\
-0.1241\end{array}$ & $\begin{array}{r}1.0000 \\
0.3547 \\
0.2970 \\
-0.0535\end{array}$ & $\begin{array}{r}1.0000 \\
0.2848 \\
-0.0505\end{array}$ & $\begin{array}{l}1.0000 \\
0.0159\end{array}$ \\
\hline var 8 & $\frac{\operatorname{var} 8}{1.0000}$ & & & & & & \\
\hline
\end{tabular}

Here we see no star sign. Therefore, the problem of Multicollinearity is solved. 


\section{The regression equation}

Now after solving main econometric problems, we are ready to find the simultaneous equation of the growth rate of the Garments Export. The equation is constructed below from the regression output:

The Growth Rate of Garments Export,

$\mathrm{G}=-.015-.228 \times 1+.022 \times 2-1.456 \times 3+2.034 \times 4+.314 \log \times 5-.134 \times 6-.119 \times 7$

Where,

-.015 is the intercept,

$\mathrm{X} 1$ is the growth rate of Interest rate,

$\mathrm{X} 2$ is the growth rate of the Inflation Rate,

$\mathrm{X} 3$ is the growth rate of the exchange rate,

$\mathrm{X} 4$ is the growth rate of GDP,

$\mathrm{X} 5$ is the growth rate of the credit provided to public sector,

$\mathrm{X} 6$ is the growth rate of stock market capitalization,

$\mathrm{X} 7$ is the growth rate of the unemployment rate.

\section{Beta Calculation}

The beta concept will be utilized to know the individual effect of the macroeconomic variables on the growth rate of garment export. In beta concept, the role that market index plays will be played by the independent variables and the stock index role will be played by the garment export variable. By beta, we understand the extent to which any stock is influenced by the deviation of market index. It is also a measure of risk. But in this analysis, beta will only be used as the measure of the extent of influence not as the measure of risk. The measured betas in terms of every independent macroeconomic variable are shown in the following table:

Beta

\begin{tabular}{|l|l|}
\hline Related variables & Garment Export \\
\hline Interest rate & -0.447098017 \\
\hline Inflation rate & 0.050660928 \\
\hline Exchange rate & -0.299990634 \\
\hline GDP & 1.687680816 \\
\hline Credit provided to Public & 0.251498993 \\
\hline Stock market capitalization & -0.031051114 \\
\hline Unemployment rate & 0.077839362 \\
\hline
\end{tabular}

\section{Comment about the betas}

In the above table the calculated betas are shown. From the table we can point out the following important points:

- Individually none of the variables influences the growth rate of garment export so much,

- The influence extent of each variable is very low,

- Except GDP none of the variables has a coefficient more than 1,

- The negative betas mainly imply very low influence on the garment export of the variables,

- Finally, it can be said that separately deviations in any of the variables do not significantly influences the export growth rate of Garments and this result supports the result found by graphical analysis. 


\section{Qualitative analysis related to the Economy and political stability}

Now we will see the qualitative analysis of this research paper. About the topic, in different times different important comments have been made by different important person. A brief analysis of those comments has been provided below:

In the Judgment of European and US CPOs, economy and political constancy is the sixth zone of risk when tracing in Bangladesh. About half of the CPOs interviewed specified that they would decrease the value of their sourcing in Bangladesh if political steadiness were to decline. Preparation of security, political turbulence and forays, sleaze, and ease of doing business are the issues revealed most often. Bangladesh's combined democracy is branded by two hefty opposing parties and a five-year election sequence. The undercurrents of the country's government have partly contributed to disruptions in short-term preparation and implementation of long- term projects.

Mass strikes (identified locally as "Hartal") have less repeatedly directly affected the RMG industry in current times, but political turbulence and raids in the supply chain can be a clue to momentous postponements. In McKinsey's investigation, Bangladesh's RMG providers mentioned political turbulence (50 percent of respondents) and strikes (21 percent of respondents) as the highest risks in sourcing from Bangladesh, right after infrastructure (McKinsey, 2011). The "Hartal phenomenon," as the local media call it, is not only a signboard for the continual social vicissitudes required, but a danger of which purchasers need to be conscious.

The mainstream of CPOs realizes corruption as a chief obstacle for doing business in Bangladesh. Some 57 percent of interviewees are cognizant of dishonesty being present but manageable with experience, whereas 30 percent have perceived boundaries in their business relations because of it. Bangladesh's situation in the Transparency Corruption Index has upgraded over the last few years, but procedures against dishonesty need to become more operative. In the view of CPOs and providers as well as international NGOs, the implementation of law and order is ineffective - or as one CPO set it: "Laws exist, but the government does not enforce application." (Berg, Hedrich, Sebastian, \& Tochtermann, 2011)“Our government is busy with how they can remain in position; they don't even bother to look how they can improve the economic condition of this country." (Manager, Sunman Group). "Of course, the macroeconomic variables affect our normal business operation. The fluctuation in the exchange rate of dollars seriously influences the garment export." (Manager, Opex Group) “We try to help the government in every possible way we can but when the time comes for some help from the government, we hardly find them on our side." [President, BGMEA: This comment has been collected from the Financial Express, Dated: 12-12-11]. "The Hartal and other ways of striking are not only harming the regular activities of us but also ruining the reputation of our country among the foreign officials which will affect the garment industry in the long run."[President, BKMEA: This comment has been collected from the annual report of BKMEA]

\section{FINDINGS AND RECOMMENDATIONS}

This research paper discussed a new concept commonly known as Beta. This concept is used here slightly differently from the way it is normally used. It is used for knowing the individual effect on the garments export of each of the variables. The variables used here are: Garments Export, Interest rate, Inflation rate, Exchange rate, GDP, Credit provided to the public, Stock market capitalization and the unemployment rate. In data analysis part, four methodologies have been used for analysing the data. They are: Graphical analysis, multiple regression analysis, Beta calculation and a brief qualitative analysis. 
From the graphical presentation of the data we find that, every variable influences the garments export more or less. But it cannot be an answer of any research; this is the reason we went far deep into the research.

Then a multiple regression analysis has been made to know the extent to which these variables affect the garment export growth rate. From that analysis, it has been found that about $70 \%$ variations in the growth rate of garments export can be defined by these variables. Then an equation for predicting future garments export has been constructed.

After this, for knowing the individual effect of the variables, beta concept has been employed and from that analysis it has been found that no variable affect garments export to a large extent. At last some comments of some important persons have been analysed, and that analysis implies that the macroeconomic variables surely affects the growth rate of garment export.

At the end of the analysis it can be said that individual effect of the macroeconomic variables on the growth rate of garments export is not much but when they are combined, they can influence the garments export growth rate. As they are also related with each other which means change in one macroeconomic variable may change all the other variables. Therefore, a combined effect always remains. So, we can say that, macroeconomic variables influence the garment industry of our country but not to a great extent. From the RMG industry viewpoint, long-term strategies and investments to accommodate the foreknown future evolution are most significant. The government's top 4 priorities for focus are infrastructure, education, structure and trade support. As formerly noted, the existing infrastructure investments are an inception but are distant from adequate to either deliver the capability needed today or come adjacent to what is compulsory for the future. Enlarged investments, meticulous planning, and scheme management, as well as overcoming superfluous bureaucracy and sleaze are required. If the infrastructure is delivered, supplementary incentives to decentralize the industry could maintenance its healthy development. The outlay in education necessitates broad initiatives. On one hand, intermediate management training should be united with a determination to improve the appearance of the apparel industry. And on the other, job-related training needs to be established, and the suitable institutions must be instituted either by the government or via public-private partnerships. Continual trade assistance for Bangladesh's RMG industry, particularly with regard to mutual agreements, is the third fundamental priority. For the latter, the attention shouldn't be on trade markets only, but a longer-term approach needs to be established in order to secure the requisite raw materials supply as well. Further sustenance in increasing the country's appeal and permitting national backwards integration in Bangladesh would benefit further to lessen dependencies.

These are the extents in which providers most strongly plea for government investment, with 97 percent of suppliers requesting for investment in infrastructure, 79 percent in training, and 50 percent in trade funding. Supplementary emphasis extents for the government from an RMG industry viewpoint should be social/health, environment, and law and order. (Berg, Hedrich, Sebastian, \& Tochtermann, 2011)

The following points state some directions for the development of the garments export:

- As the garments export is less influenced by the macroeconomic variables, government should try to concentrate on the development of new foreign market,

- The credit to the public sector should be increased as this variable positively influences the growth rate of garments export,

- The government should not take any step to make this stable position of the garments industry vulnerable to any macroeconomic changes,

- Proper initiatives should be taken to keep up the pace of the garment export in the following years. 


\section{REFERENCES}

Absar, S. S. (March 2000). Conditions, concerns and needs of garment workers in Bangladesh. Development Bulletin , 82-84.

Acevedo, L. G., Robertson, R., Frederick, S., Gamberoni, E., Abras, A. L., Savchenko, Y., et al. (2012). Sewing Success? Washington D.C.: The World Bank.

Ahmed, N. (2009). "Sustaining Ready-made Garment Exports from Bangladesh. Journal Of Contemporary Asia , 597-618.

Alam, K., Blanch, L., \& Smith, A. (2011). War On Want. London: War on Want, 44-48 Shepherdess Walk, London N1 7JP, United Kingdom.

Ara, D. A., \& Rahman, M. (2010, June 16). The Competitiveness and Future Challenges of Bangladesh in International Trade. Retrieved June 14, 2012, from http://www.wto.aoyama.ac.jp: http:/ /www.wto.aoyama.ac.jp/file/090126laila_paper.pdf

Arnold, J. (2010). Effects of Trade Logistics on the Strategy of the Garments Industry for Product and Market Diversification. Dhaka: World Bank.

B.Gowthaman, \& Prasanna, R. (2007). Sector Specific Living Wage For Sri Lankan Apparel Industry Workers. Srilanka: Alarm.

BBS. (Bangladesh Progress at a Glance). Millenium Development Goals. Dhaka: Bangladesh Bureau of Statistics.

Berg, D. A., Hedrich, S., Sebastian, K., \& Tochtermann, T. D. (2011). Bangladesh Ready-made Garments Landscapes: The Challenge of Growth. McKinsy \& Company. Europe: McKinsy \& Company.

Berman, J., \& Pfleeger, J. (1997). Which industries are sensitive to business cycles? Monthly Labor Review , $19-25$.

BGMEA. (2009, July 01). About us. Retrieved August 15, 2012, from Bangladesh Garment Manufacturers And Exporters Association (BGMEA): http://www.bgmea.com.bd/home/pages/aboutus

BGMEA. (2009, July 01). News and Events. Retrieved 5 21, 2012, from BGMEA: http://bgmea.com.bd/

BKMEA. (2010-11). Appare Export Statistics of Bangladesh. Dhaka: BKMEA.

BKMEA. (2010, July 01). BKMEA At A Glance. Retrieved August 16, 2012, from BKMEA: http://www.bkmea.com/at_a_glance.php

Bogdan, R. C., \& Biklen, S. K. (1982). Qualitative research for education: An introduction to theory and methods. Boston: Allyn and Bacon Inc.

Bonoma, T. (1985). Case Research in Marketing: Opportunities, Problems, and a Process. Journal of Marketing Research , 28, 353-374.

Cenesizoglu, T. (2010). Size, Book-to-Market Ratio and Macroeconomic News. Montreal: Department of Finance, HEC Montreal, 3000.

Creswell, J. (1994). Research design, qualitative and quantitative approaches. California: Sage Publications.

Decorp, A. (1999). Triangulation in qualitative tourism research. Tourism Management, , 20, 157-161.

Domat, G., Glass, B., \& Brown, D. (2012). The Apparel Industry: Jordan's Comparative Advantage in International Trade. Jordan: Tufts University.

DOT (Department of Textiles). (2009). Survey of the Bangladesh Textile Industry to Assess the Requirement of Textile Technologists. Dhaka, Bangladesh: Department of Textiles.

European Commision. (2001). Guidebook for European Investors in Bangladesh. Dhaka: European Commision, Asian Investment Facility.

Evert, G. (2000). Qualitative Methods in Management Research (2nd ed.). London: Sage Publications.

Fischer, S. (2001). Growth, Macroeconomics, and Development. Massachussets: MIT Press.

Gephart, R. P. (2004). From the Editors - Qualitative research and the Academy of Management Journal. Academy of Management Journal , 47 (4), 454-462.

Haan, E. d., Koen, M., \& Mthembu, N. (2002). garment production in Malawi. Durban: SOMO and Workers College.

Habib, M. R. (2009). Backward Linkages in Readymade Garment Industry of Bangladesh: Appraisal and Policy. Journal of Textile and Apparel, Technology and Management , 6 (2), 1-11.

Haider, Z. M. (2007). Competitiveness of the Bangladesh Ready-made Garment Industry in Major International Markets. Asia-Pacific Trade and Investment Review , 8-22.

Halfpenny, P. (1979). The analysis of qualitative data. Sociological Review (New series) , 27, 799-825. 
Hoque, Z. (2006). Methodological issues in accounting research: Theories and methods. London: Spiramus Press Ltd.

Islam, Z. K. (2007). Bangladesh Garment Industry In Global Context, Finnish Perspective. Lahti University of Applied Sciences, Faculty of Business Studies. Lahti: Lahti University of Applied Sciences.

Iwan Hermawan. (2011). Analysis Of The Impact Of Macroeconomic Policies On Textile Industry And Its Products In Indonesia. Bulletin of Monetary, Economics and Banking , 357-390.

Khaled, S. M. (2011). Problems of Bangladesh Garments Sector and their Solution- An Islamic Perspective. Thoughts on Economics , 20 (03), 23-50.

Khosla, N. (2009, November 01). The ready-made garments industry in Bangladesh: A means to reducing gender-based social exclusion of women? Journal of International Women's Studies, pp. 289-303.

King, N. (2004). Using interviews in Qualitative research, Essential Guide to qualitative Methods in Organisational Research. (C. Cassell, \& G. Symon, Eds.) London : Sage publication .

Koyi, G. (2006). The Textile and Clothing Industry in Zambia. Friedrich-Ebert-Stiftung , 255-274.

Kvale, S. (1996). Interviews: An Introduction to Qualitative Research Interviewing. London: Sage Publications.

Lee, T. (1999). Using Qualitative Methods in Organizational Research. London : Sage Publications.

Maanen, V. (1998). Qualitative studies of Organisations. London : Sage Publications.

Marwaha, A. (2008). Impact of China on Indian Garment Industry. Nottingham: The University of Nottingham.

Mason, J. (2002). Qualitative Researching. London: Sage Publication.

McKinsey, \&. C. (2011). Bangladesh's Ready-made Garments Landscape: The Challenge of growth. Dhaka: BGMEA.

Miles, M., \& Huberman, A. (1994). Qualitative data analysis. London: Sage Publications.

Mirdha, R. U. (2012, January 01). Govt to fund training for garment workers. Retrieved 5 21, 2012, from The Daily Star: http:/ / www.thedailystar.net/newDesign/news-details.php?nid=235173

Oppenheim, A. (2000). Questionnaire Design, Interviewing and Attitude Measurement. Newyork: Continuum.

Osman, A. S. (2012, June 25). Exporting garments. (M. Rahman, Interviewer)

Patton, M. Q. (1987). How to Use Qualitative Methods in Evaluation. California: Sage publications.

Quddus, Munir, \& Rashid, R. (2000). Entrepreneurs and Economic Development: The Remarkable Story of Garment Exports from Bangladesh. Dhaka: The University Press Limited.

Rahman, M., \& Anwar, A. (2006). Bangladesh Apparels Export to the US Market: An Examination of Her Competitiveness vis-à-vis China. Centre for Policy Dialogue.

Raihan, M. S. (1999). The Textile and Clothing Industry of Bangladesh: In a Changing World Economy. Dhaka: Centre for Policy Dialogue.

RASHID, M. A. (2006). Rise of Readymade Garments Industry in Bangladesh: Entrepreneurial Ingenuity Or Public Policy. Dhaka: Bangladesh Institute for Development Studies.

Razzaue, A., \& Eusuf, A. (2007). Trade, Development and Poverty Linkage: A Case Study of Ready Made Garment Industry in Bangladesh. Unnayan Shamannay , 4-8.

Rubin, H. a. (1995). Qualitative Interviewing: The art of hearing data. Thousand Oaks, CA: Sage publications.

Saheed, H. (2008). Prospects for the Textile and Garment Industry in Bangladesh. Textile Outlook International (135), 12-48.

Sapsford, R., \& Jupp, V. (2006). Data Collection and Analysis. London: Sage Publications.

Seale, C. (1999). Quality in Qualitative Research. Qualitative enquiry , 4, 465-478.

Silverman, D. (2000). Doing Qualitative Research. London: Sage Publications.

Unnayan Onneshon. (2010). Bangladesh Economic Update: Growth, Tax, Inflation and Consumers. Dhaka: Unnayan Onneshon.

Wikipedia. (2012, July 12). Bangladesh. Retrieved July 15, 2012, from Wikipedia: http:/ /en.wikipedia.org/wiki/Bangladesh

Wikipedia. (2012, June 21). Bangladesh Textile Industry. Retrieved July 15, 2012, from Wikipedia: http://en.wikipedia.org/wiki/Bangladesh_textile_industry

World Bank. (2005). End of MFA Quotas-Key Issues and Strategic Options for Bangladesh Readymade Garment Industry. Dhaka: Poverty Reduction and Economic Management Unit, World Bank. 
Yamagata, T. (2007, April 04). Prospects for Development of the Garment Industry in Developing Countries: What Has Happened Since the MFA Phase-Out? Retrieved June 14, 2012, from http:/ /hdl.handle.net/2344/551:

http://ir.ide.go.jp/dspace/bitstream/2344/551/3/ARRIDE_Discussion_No.101_yamagata.pdf

Younus, M., \& Yamagata, T. (2012). Dynamics of the Garment Industry in Low-Income Countries: Experience of Asia and Africa(Interim Report). IDE-JETRO. Japan: IDE-JETRO.

$--0--$ 